primer. The two papers describing this discovery were first rejected by the Journal of Biological Chemistry, but rescued by the then new chief editor, John Edsall. The Nobel prize awarded to Kornberg (with Ochoa) in 1959 did not turn his head; he returned from Stockholm with his enthusiasm for research undiminished.

There was great excitement when DNA polymerase duplicated an infectious $\varphi \chi$ DNA, but the story was blown out of proportion by the press. When it later became clear that this is not how DNA is synthesized, but how it is repaired, some complained that Kornberg had overstated his case. Although probably painful at the time, it stimulated Kornberg to start from the beginning in his search for the mechanism of DNA replication.

Kornberg picked a new system, the filamentous phage $M_{13}$ (a lucky choice, he says), and persuaded his entire group to join him in the adventure. They found that RNA synthesis is required for DNA duplication, but from then the story became more and more complex. After 17 years of work on DNA synthesis, Kornberg is still "grappling with its awesome complexity".

Over a dozen proteins were discovered by methods of biochemical resolution and genetic complementations. He predicts that over 20 components are required and that it will take decades before we fully understand the DNA-replicating machinery. Year after year new discoveries are being made and even certain phospholipids, capable of releasing tightly bound and inhibitory ADP from DNA A protein, appear to be involved. Could such a mechanism have a part in some of the $G$ proteins that tightly bind inhibitory GDP?

Kornberg is an innovator in more than his own research. His department at Stanford, where all share funds, fun and discoveries, is unique. He was, and is, a demanding mentor. At NIH, Bill Price, his gentle technician, once failed properly to balance a set of centrifuge tubes and the tube broke. Kornberg chided him that "the hour lost can never be recovered". On another occasion, when Kornberg had failed to understand a Brazilian postdoctoral fellow, he asked him what he was driving at. The response was, "Me driving? No! You drive! You drive all the time!".

Kornberg's opinions of the conduct of science are scattered through his book. He believes, for example, that the role of $\mathrm{NIH}$ in the history of medical science has been undervalued, saying that "the achievements of NIH defy exaggeration". Members of Congress would do well to read the passage concerned (pp.129-135), and do more to preserve that endangered species, the NIH researcher.

On the atmosphere of secrecy emerging from the inevitable and potentially beneficial marriage between industry and the universities, Kornberg takes a paradoxical line: "I believe that secrecy makes even less sense in an industrial setting than in an academic one. The best insurance for industrial success is an open atmosphere that provides optimal access to all information and advice. As significant advances are made, inventions can be protected each step along the way by a patentapplications team that interacts on the spot continually and knowledgeably with the scientists. In contrast, a company policy of secrecy closes the avenues of exchange with academic scientists and prevents useful collaborations with other companies. It is generally unappreciated that secrecy within the company itself shelters mediocrity and discourages the vigorous exchange that identifies excellence". Will his cogent arguments persuade the leaders in industry? I wish I could be optimistic about this. But they might heed his other suggestion, that a partnership between academic science and industry might be effective in lobbying Washington

\section{On form}

\section{S.J. Perkins and S.A. Baldwin}

Protein Structure: A Practical Approach. Edited by T.E. Creighton. IRL Press: 1989. Pp. 355. Hbk £30, \$65; pbk £20, $\$ 40$.

The Practical Approach series now has over 40 titles under its banner. This new addition, edited by T.E. Creighton, describes experimental techniques for the study of protein structures. Such structures are usually investigated because of the light they might throw on function, a property of proteins which is not discussed here (a companion volume is concerned with that topic). Moreover the book is largely concerned with globular, watersoluble proteins; both fibrous proteins (about half the protein in the human body!) and membrane proteins receive little mention.

Despite its title, the book also does not deal with the determination of protein primary structures (again, a topic covered by a different volume in the series). Nor does it deal with atomic structure determinations requiring sophisticated equipment. Instead, it presents a collection of simple techniques for the analysis of protein structure that could be performed in most biochemical laboratories. The description of each technique is prefaced by a brief introduction, implying the need for some background knowledge on the part of the reader. But the practical details are clear and will be easy to follow even for those with little experience of similar techniques.

Six of the 14 chapters are concerned for support for basic science.

Kornberg is a gifted writer and the book contains sentences of both wisdom and beauty. Thus (on p.274): "The tides of fashion in science erode one beach to create another. In the rush and excitement of the new mastery over DNA, training in enzymology and its practice have been neglected. Most of our students are introduced to enzymes as commercial reagents, and they find enzymes as faceless as buffers and salts”. Or (p.298): “. . . DNA and genes captured the spotlight from enzymes; but in my theater, enzymes kept the leading role. DNA and RNA provide the script, but the enzymes do the acting".

For the Love of Enzymes is at the same time charming, stimulating and informative, a reflection of its author. If widely read - and I very much hope it is - it will greatly contribute to the scientific education of the public.

Efraim Racker is Albert Einstein Professor of Biochemistry, Cornell University, Ithaca, New York 14853, USA.

with various aspects of gel electrophoresis, including $M_{\mathrm{r}}$ estimations, isoelectric focusing, two-dimensional gel electrophoresis and peptide mapping. Scheidtmann gives a comprehensive account of the generation of antibodies to synthetic peptides for protein identification and characterization, while Friguet and colleagues provide a very helpful introduction to the immunochemical analysis of protein conformation.

Most of the remaining chapters also deal with protein conformation. In the light of the DNA-sequencing revolution, one of the most timely is that from Argos on structural predictions from sequences; this is a straightforward survey of how to determine a DNA reading frame, how to search for and align homologous sequences, and how to predict secondary structure and then plan site-specific mutagenesis experiments. There are also several contributions on the analysis of protein folding and stability, and on spectroscopic techniques for the determination of conformation and conformational changes. The coverage is fairly comprehensive, although omission of the increasingly popular technique of Fourier transform infrared spectroscopy for the determination of protein secondary structure is surprising.

Volumes in the Practical Approach series have become standard laboratory equipment. This one is no exception, and we must hope that the series stays on course under the new management of Oxford University Press.

S.J. Perkins and S.A. Baldwin are in the Departments of Biochemistry and Chemistry, and of Protein and Molecular Biology, at the Royal Free Hospital School of Medicine Rowland Hill Street, London NW3 2PF, UK. 